\title{
What Drives Interest Rate Spreads in Uganda's Banking Sector?
}

\author{
Dorothy Nampewo
}

Correspondence: Dorothy Nampewo, Economic Policy Research Centre, Plot 51 Pool Road, Makerere University, P.O Box 7841, Kampala, Uganda. Tel: 256-712-748-448. E-mail: dmnampewo@gmail.com

Received: September 10, $2012 \quad$ Accepted: November 15, $2012 \quad$ Online Published: December 10, 2012

doi:10.5539/ijef.v5n1p76 URL: http://dx.doi.org/10.5539/ijef.v5n1p76

\begin{abstract}
This paper investigated the main causes of the continuously large interest rate spreads in Uganda's banking sector for the 1995 to 2010 period. The main approach used was the test for cointegration where the Engle and Granger (1987) two-step procedure was applied to test for the long-run relationship. The error correction model was applied for short run relationship with the error correction term to determine the speed of adjustment between the short-run and the long-run. The variables that were investigated in this study included the bank rate, the treasury bill rate, exchange rate volatilities (XRTV), M2/GDP and the proportion of non-performing loans to total private sector credit. The empirical results show that the bank rate, treasury bill rate, and non performing loans significantly and positively affect the interest rate spreads, M2/GDP and real GDP were significant and negatively influence interest rate spreads both in the short and long-run period.
\end{abstract}

Keywords: interest rate spreads, financial reforms, banking sector

JEL Classification: E43, E52

\section{Introduction}

In the early 1990s, Uganda, like other emerging economies, embarked on the process of financial liberalization. One of the key objectives of financial liberalization was to increase the efficiency of the financial system as would be evidenced from the reduction of interest rate spreads- the difference between average lending rates and average deposit rates in the banking system (Sologoub, 2006).

Contrary to the expectations of the financial reforms, interest rate spreads have remained large and volatile in Uganda. Figure 1 shows that interest rate spreads were increasing and volatile before the financial reforms that is, between 1990 and 1992. After the reforms in1993, interest rate spreads continued to rise. The line in Figure 1 separates the period before and after financial reforms in Uganda. According to Bank of Uganda quarterly report, 2008, the large and volatile spreads have hindered provision of long-term lending in Uganda.

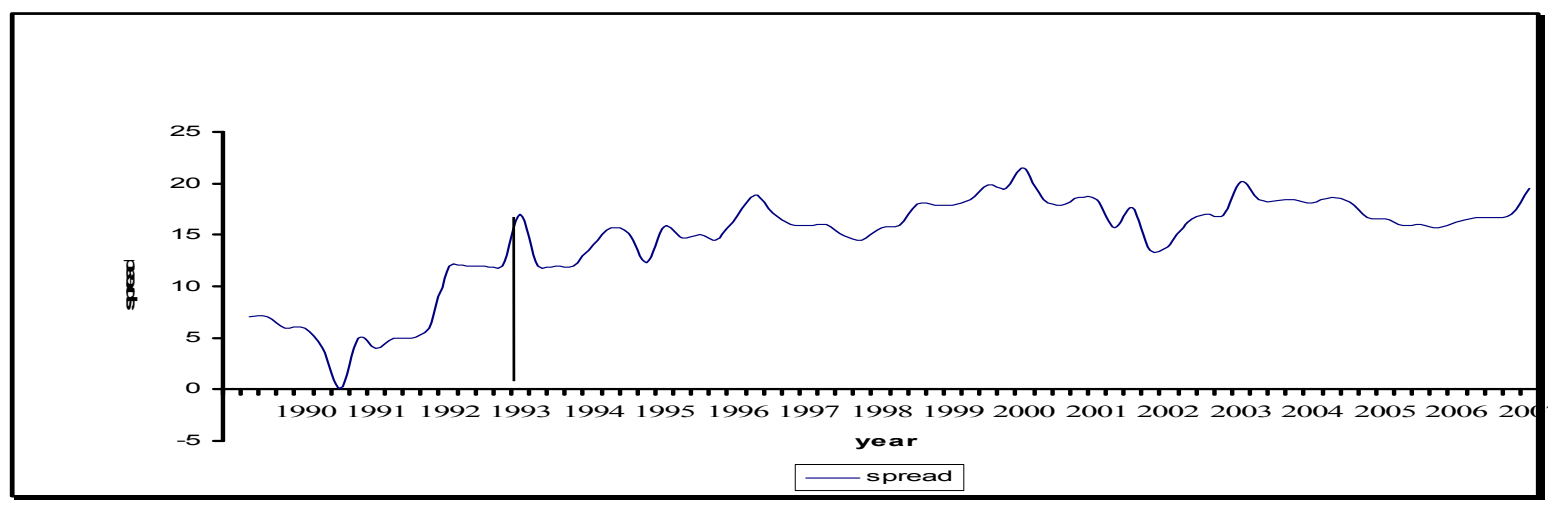

Figure 1. Interest rate spreads before and after financial reforms in Uganda

Source: Bank of Uganda, various issues

Kasekende, 2003 highlighted lack of competition and high operational inefficiency within Uganda's banking sector as the major factors driving large spreads in Uganda. As a solution to this challenge, bank of Uganda lifted 
the moratorium on commercial banks to allow for more banks in the financial system. The expectation from this intervention was that more financial institutions would increase competition and efficiency in Uganda's banking sector and hence reduce the interest rate spreads. Since the lifting of the moratorium in 2005, commercial banks have increased from 16 in 2005 to 25 in March 2012. However, this intervention seems not to have delivered to its expectations because interest rate spreads have remained large and volatile to date. This is the motivation behind this study that investigated the factors driving the persistent large interest rate spreads in Uganda's banking sector

The rest of the paper is organized as follows: Section two reviews Uganda's banking system and the evolution of interest rates, while section three explores the empirical and theoretical literature on the main drivers of spreads. The model specification and the estimation procedure are described in section four. The empirical analysis is presented in section five while conclusions and policy implications are drawn in section six.

\section{An Overview of Uganda's Banking System and Evolution of Interest Rates}

\subsection{Uganda's Banking System}

Uganda's banking system comprised of only four commercial banks in the early 1960s. These included; Standard Chartered, Barclays, Grindlays and Bank of Baroda. These were foreign owned banks that were widely criticized for short-term lending and biased provision of financial services to foreign companies leaving financial access for the locally owned companies limited and hence threatening the development objective of government. It was therefore argued that government intervention was required to the extent that banks did not pursue a developmentalist role (Brownbridge, 1998).

Against this background, government of Uganda embarked on a program to extend credit services to indigenous enterprises. This was done by establishing the Uganda Commercial Bank, which arose from reshaping the member based Uganda Credit and Savings Society. As a result of this transformation, the Uganda Commercial Bank took over management of all government transactions from foreign banks and thus the indigenous companies were more involved in terms of access to financial services.

In 1992, government embarked on the process of financial sector liberalization. This process mainly consisted of interest rate control reforms which led to the introduction of a treasury bill auction. To further elucidate the role of bank of Uganda as the regulator of all financial institutions in Uganda, the financial institutions bill and central bank charter were enacted in 1993. This was further followed by the process of interest rate liberation which allowed the removal of restrictions from commercial banks' operations and holding of assets.

The process of financial liberalization led to entry of many new foreign and domestic banks. However, this resulted into a major banking crisis characterized by inadequate bank capital and high rates of non-performing loans within the banking system (Caprio et al 2005). This crisis led to closure of weak banks including, Greenland bank and the Co-operative bank. The banking crisis resulted into government intervention through bank of Uganda to renationalize UCB.

The renationalization process ended up by selling 80 percent of UCB's shares to stanbic bank and the remaining 20 percent were left to the government (Clarke et. al, 2006). Generally overtime, implementation of the reforms has greatly strengthened the banking system in terms of capitalization, profitability and resilience.

To date, Uganda's formal financial system comprises of commercial banks -Tier 1; which constitute the biggest component the financial system, bank-like institutions -Tier 2, microfinance deposit-taking institutions-Tier 3, The National Social Security Fund (NSSF), one Post-bank, 18 insurance companies, 3 development banks, 88 forex bureaus and one stock exchange- the Uganda Securities Exchange. The informal sector constitutes money-lenders, savings and credit cooperative societies (SACCOs) as well as rotating savings and credit association (ROSCAs)

\subsubsection{Banking Performance}

The lifting the moratorium in 2005 led to opening up of nine new commercial banks bringing the total number of banks in Uganda to 25 in 2012. On the overall, Uganda's banking system has continued to expand with an average bank branch network of up to 366 branches in March 2012. In terms of asset holdings, commercial banks have experienced stable growth since the lifting of the moratorium in 2005. During this period, commercial banks' total assets rose from a total of shs 2,991 billion in 2003 to shillings 13.5 trillion in 2012. Similarly total liabilities grew by the same amount in the same period.

Most of the growth was driven by loan advances to customers which increased from shs 855 billion in 2003 to shillings 6,515 billion in 2011. Regarding the liabilities, the increasing deposits accounted for most of the growth in liabilities. Total deposits increased from shs 2,115 billion in 2003 to shs 8,709 billion in 2011. Figure 2.shows the proportion of total commercial banks assets to total liabilities before and after the lifting of the moratorium in 
2005.

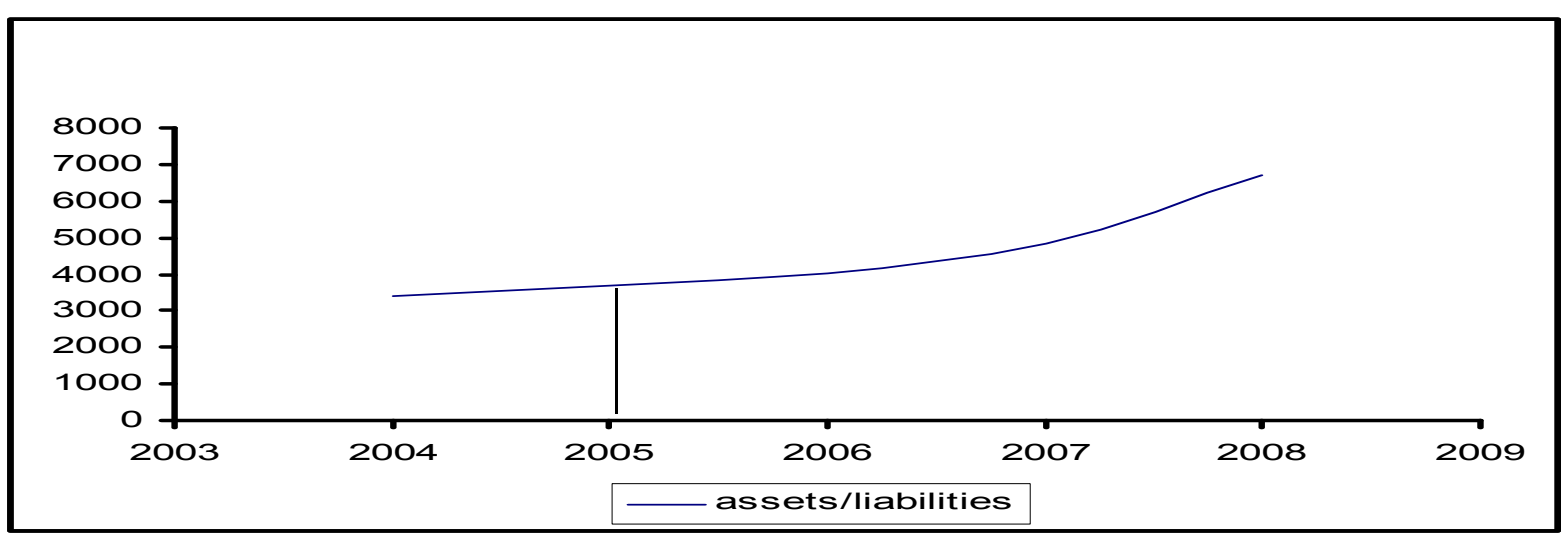

Figure 2. The proportion of total commercial banks assets to total liabilities (shs. Billion)

Source: Bank of Uganda, various issues

Similarly commercial bank profitability has steadily improved. Between 2003 and 2011, profits after tax increased from shillings 123 billion in 2003 to shillings 488.85 billion in 2011. Figure 3 shows the trend of the commercial banks profits after tax before and after the lifting of the moratorium in 2005. However, since 2005 this trend has not changed as bank behavior and responses to private lending has remained the same.

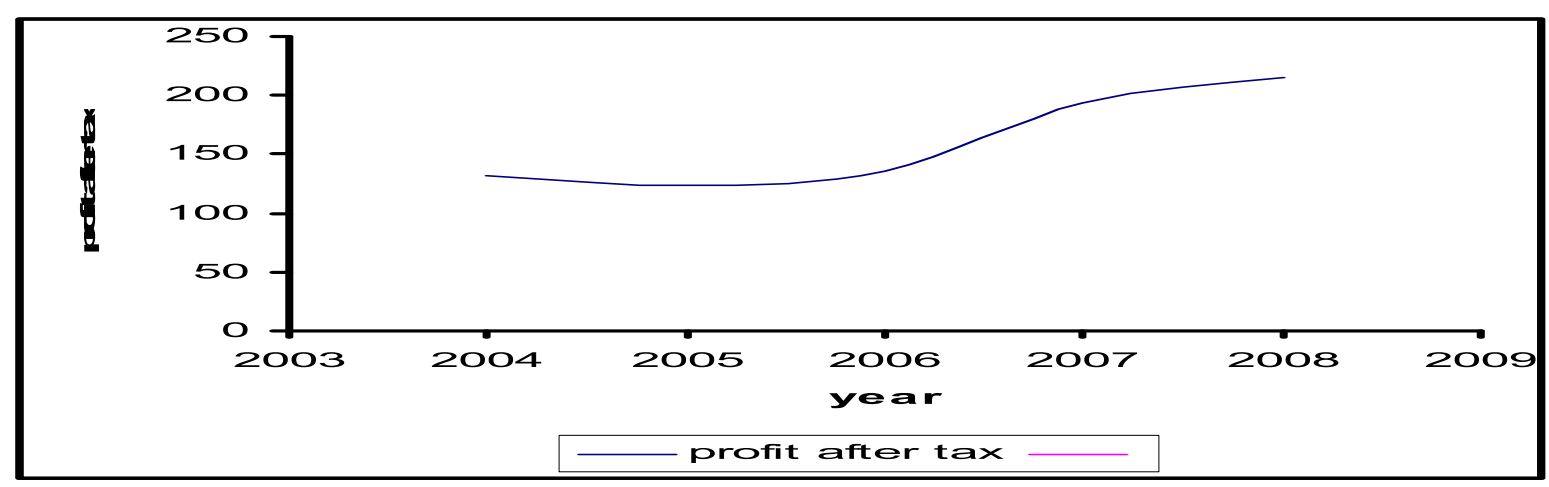

Figure 3. Uganda's commercial banks' profits after tax (shs. Billion)

Source: Bank of Uganda, various issues

\subsection{Evolution of Interest Rates}

In 1994, government of Uganda embarked on implementing the process of liberalizing interest rates. This process involved adjusting nominal interest rates to match the inflation rate as a way of ensuring positive real interest rates. This was followed by shifting the treasury bill market from adhoc issues to a market based auction system. This shift led to market determined treasury bill rates which were then used as the monetary policy instruments by the central bank.

The liberalization of interest rates had a marginal effect on Uganda's interest rates as reflected in the fall of interest rates from an average of 40 percent before liberalization to 20 percent after the liberalization process (see Figure $4)$. 


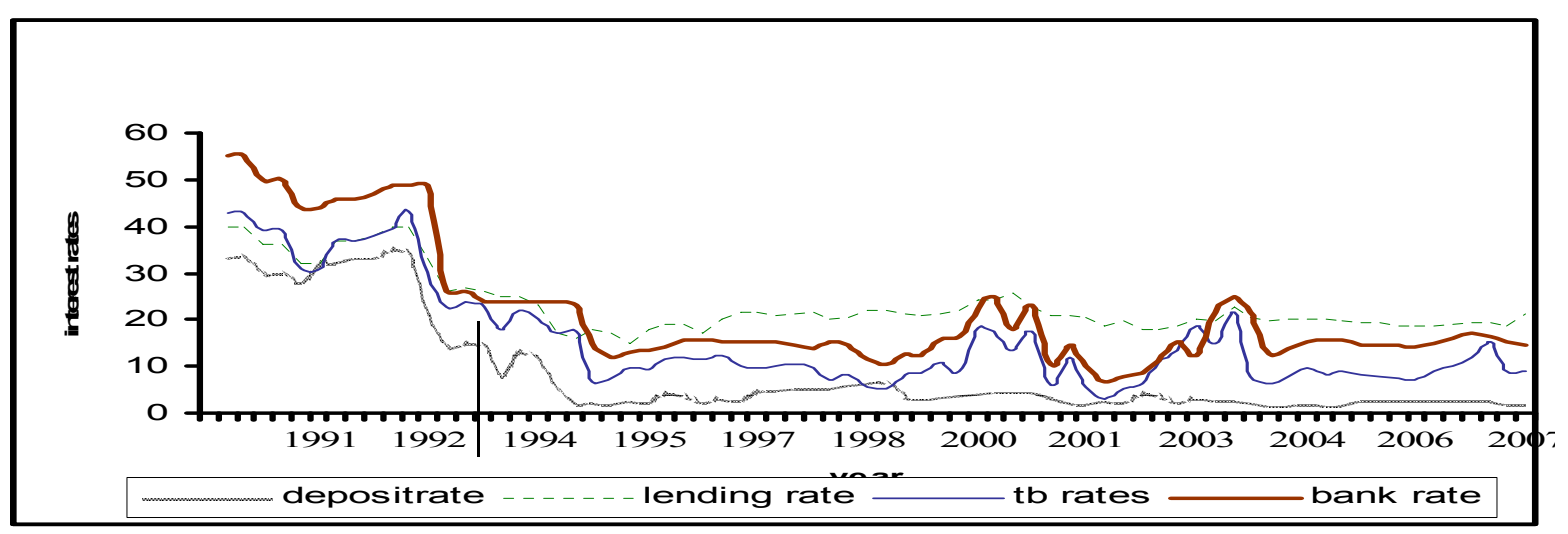

Figure 4. Interest rates before and after interest rate liberalization

Source: Bank of Uganda, various issues

\section{Review of Related Literature}

\subsection{Analytical Framework}

The analytical framework is based on the McKinnon and Shaw (1973) paradigm. According to this framework, McKinnon (1973) argues that removing financial restrictions from the financial system results into a considerable improvement of the economies' growth processes. This will occur in such a way that high interest rates attract households to save with the financial institutions and as a result bank deposits rise and hence an increase in banking efficiency

Additionally, Shaw (1973) focuses on the role financial intermediaries have to play in development. Financial liberalization in terms of increasing interest rates springs mainly from expanding the amount of financial intermediation occurring between savers and investors due to increased efficiency of the banking sector and lower level of spreads. The increase in investment funds causes an increase in the quantity of investment. He further argues vehemently that real cost of borrowing declines significantly and the average efficiency of investment is raised due to the fact that banks would be realizing economies of scale through risk diversification, lending and operational efficiency. This ultimately reduces the interest rate spreads.

\subsection{Empirical Literature}

The main determinants of interest rate spreads in banking institutions are classified into bank specific, market specific and macroeconomic factors. For example Demirguc-Kunt et. al, 1998, Moore et. al, 2000 and Sologoub (2006) argued that the major drivers of interest rate spreads are the bank specific factors such as; the bank size, bank ownership, the loan portfolio, capital adequacy, overhead and operating cost, and shares of liquid and fixed assets. In fact Beck et.al, 2006 agree with this and further stress that interest rate spreads in Uganda are mainly driven by the bank size, as well as overhead costs and sectoral compositions of loans.

Turning to the market specific factors, Samuel et. al, 2006 indicates that an oligopolistic market structure results in higher spreads. This is in line with Hannan et.al, 1993 and Barajas et al, 1999, who found out that industry concentration is positively linked to higher spreads.

Regarding macroeconomic factors, in one of their more recent and broader studies of the determinants of spreads in the banking system, Demirguc et al (1999) found several variables to be correlated with higher spreads, including higher inflation, higher real interest rates, and lack of banking sector competition. They also found that some variables such as institutional features for example lack of creditor rights or corruption, and reserves matter more in developing countries than in developed countries. In a related paper, Demirgüç et al (2003) found that inflation was associated with higher bank interest rate spreads.

Randall (1998) and Gelos (2006) stressed that higher costs would logically require banks to charge higher spreads in order to remain profitable. Most studies, have reached this conclusion. Randall (1998) and Gelos (2006) pointed out many sources of higher costs that have different implications for other aspects of bank management. The sources included personnel costs, required reserve ratios, poor governance, non performing loans, and general inefficiency. Higher capital to asset ratios would also increase costs, though the direction of causation in this relationship could be uncertain. 
In fact the non performing loans are one the critical drivers of large spreads as bankers tend to offset "bad loans" by charging high lending rates. This argument was also fronted by Barajas et al (1999), Robinson (2002) and Meyer, et al., (2004) who argue that fraud incidences and lack of credit information sharing on borrowers result into high rates of nonperforming loans and hence increasing bank spreads.

From the literature, it can be concluded that the main driving factors of large interest rate spreads include; inflation rates, exchange rate volatilities, the discount rate, reserve requirement, credit to the government, level of banking efficiency, bank concentration, the nature of banks as to whether they are foreign banks or domestic banks, operating and overhead costs of the banking sector, real interest rates, treasury bill rates, bank size, non performing loans and sectoral composition of loans.

\section{Methodology}

\subsection{Model Specification and Variables}

The main objective of this study was to investigate the drivers of high interest rate spreads in Uganda's banking sector. Based on the factors highlighted in the literature review, five explanatory variables including the bank rate, treasury bill rate, ratio of non-performing loans to total private sector credit, exchange rate volatilities (XRTV) and ratio of M2 (broad money) to GDP were selected and tested on Uganda's data stretching from 1995 to 2010. The bank interest rate spread (the difference between the average lending rates and average deposit rates) is the dependent variable.

Among the independent variables is the discount rate (bank rate). This measures the cost of commercial banks' borrowing from the central bank. The discount rate is expected to be positively related with the spread.

The 91-day- treasury bill rate is regarded as the monetary policy instrument pursued by the central bank. Therefore, lower levels of treasury bill rates would lead to lower interest rate spreads and vice versa. The treasury bill rate is expected to be positively related with the spread.

The ratio of M2 (broad money) to GDP is an indicator of financial sector development. A well developed financial sector ensures efficient allocation of resources at acceptable and affordable interest rates. The growth in broad money (M2) reflects a rise in the level of intermediation given a wide array of financial assets and hence resulting into financial development and improved banking efficiency (Sikorski, 1996). Therefore, the ratio of M2 to GDP is expected to be negatively related to the interest rate spreads.

Uganda is a small open economy therefore it is prone to macroeconomic instabilities arising from both internal and external shocks. For purposes of this study, the exchange rate volatility (XRTV) is used as a proxy for macroeconomic instabilities. It is computed as the standard deviation of the real exchange rates for the three preceding years (Folawewo and Tennant, 2011). Further more changes in interest and inflation rates in Uganda's economy are captured by the same variable. The exchange rate volatility (XRTV) is expected to be positively related with the interest rate spreads since commercial banks are expected to increase lending rates to guard against risks arising from macroeconomic instabilities.

Finally, the ratio of non-performing loans to total private sector credit is included to capture the effect of credit risk on interest rate spreads. The higher this ratio (non-performing loans to total private sector credit) the higher the risk and the higher the level of non-current loans thus an increase in the spread.

The linkage between the interest rate spreads and the factors affecting it is specified as;

$$
s p d=f\left(b r, t b, m 2 / g d p, x r t v, n p l / c p, \varepsilon_{t}\right)
$$

The empirical specification is given as;

$$
\operatorname{spd}_{t}=\beta_{0}+\beta_{1} t b_{t}+\beta_{2} b r_{t}+\beta_{3}(m 2 / g d p)_{t}+\beta_{4} x r t v_{t}+\beta_{5}(n p l / c p)_{t}+\varepsilon_{t}
$$

where;

$\mathrm{spd}=$ interest rate spreads, $\mathrm{tb}=$ treasury bill rates, $\mathrm{br}=$ bank rate, $\mathrm{m} 2 / \mathrm{gdp}=$ ratio of $\mathrm{M} 2$ to GDP, $\mathrm{XRTV}=$ exchange rate volatilities , $\mathrm{npl} / \mathrm{cp}=$ ratio of non-performing loans to total private credit , $\mathrm{t}=$ time period, $\varepsilon_{\mathrm{t}}=$ error term

\subsection{Data Type and Data Source}

The study employed quarterly data for the 1995 to 2010 period. The main data sources were Bank of Uganda and the Uganda Bureau of Statistics. Data on average lending rates, average deposit rates, the bank rate, 
non-performing loans, credit to the private sector, exchange rate volatilities, M2, treasury bill rates was collected from Bank of Uganda and data on GDP was collected from the Uganda Bureau of Statistics.

\subsection{Estimation Procedure}

The Engle-Granger (EG) Approach (1987) was employed for this study. To ascertain the order of integration and the order of differencing needed to make each time series stationary, the Augmented Dickey-Fuller (ADF) test was used. The unit root test statistics were applied to levels as well as first differences of individual time series regression with the maximum lag of 4. Secondly, a cointegration test was employed to select the vectors of cointegrated series for the regressions to check the long run relationship between dependant variable and explanatory variables. The Error-Correction Model (ECM) was employed to check the speed of adjustment of the independent variables towards the dependent variable. Finally Diagnostic tests were carried out to test the stability and significance of the model.

\section{Empirical Results and Discussion}

\subsection{Time Series Properties}

Descriptive statistics for the data were undertaken for variables in levels. The descriptive statistics in levels showed that most of the variables satisfy the normality test. Table 1 summarizes the descriptive statistics for the series in levels.

Table 1. Descriptive Statistics for variables in level

\begin{tabular}{lllllll}
\hline & Bank rate & M2/GDP & NPL/CP & T-bill rate & XRTV & Spread \\
\hline Mean & 14.82556 & -0.171581 & -2.294050 & 9.883843 & 20.58777 & 17.27129 \\
Median & 14.70500 & -0.076710 & -2.302585 & 9.242767 & 15.89298 & 17.04463 \\
Maximum & 25.10000 & 0.582229 & -0.616186 & 21.44400 & 87.14810 & 21.32490 \\
Minimum & 6.750000 & -1.168246 & -3.912023 & 2.968518 & 0.00000 & 13.87900 \\
Std.dev & 3.928523 & 0.549654 & 1.084048 & 3.869794 & 17.88825 & 1.626142 \\
\hline
\end{tabular}

\subsubsection{Unit Root Tests}

The results of the unit root test are presented in Table 2. Unit root test results for the variables in levels indicate that all the variables were stationary at 1,5 and 10 percent levels of significance (see Table 2). This implies that the variables are integrated of order 0 .

Table 2. Unit Root test for variables in levels

\begin{tabular}{lll}
\hline Variable & ADF Statistic & Order of integration \\
\hline Spread & $-2.875327^{*}$ & $\mathrm{I}(0)$ \\
Bank rate & $-3.573740^{* * *}$ & $\mathrm{I}(0)$ \\
NPL/CP & $-3.142013^{* *}$ & $\mathrm{I}(0)$ \\
XRTV & $-5.589609^{* * *}$ & $\mathrm{I}(0)$ \\
M2/GDP & $-6.792282^{* * *}$ & $\mathrm{I}(0)$ \\
Treasury bill rates & $-4.881203^{* * *}$ & $\mathrm{I}(0)$ \\
\hline
\end{tabular}

Notes :( i) ln is the natural logarithm and ADF is Augmented Dickey Fuller.

(ii) Critical values for ADF statistics are $-3.5654,-2.9995$ and -2.5979 at $1 \%, 5 \%$ and $10 \%$ respectively.

(iii) The asterisk $* * *, * *$, and $*$ indicate significance at the 1 percent, 5 percent and 10 percent levels

\subsubsection{Cointegration Test Results}

Based on the unit root test explained in Table 2, the Engle and Granger (1987) two-step procedure was applied where the spread the dependent variable was regressed on the explanatory variables in levels and the results are presented in table 3 . The error term from the regression in Table 3 was tested for stationarity. The results are presented in Table 4. 
Table 3. Estimation of the cointegration equation by OLS

\begin{tabular}{|c|c|c|c|}
\hline \multicolumn{4}{|c|}{$\begin{array}{l}\text { Dependent variable: Interest rate spread } \\
\text { Method: Least squares }\end{array}$} \\
\hline Variable & Coefficient & Std. Error & Prob. \\
\hline Treasury bill rates & 0.227410 & 0.051811 & $0.0021 * * *$ \\
\hline XRTV & 0.0495 & 0.02354 & $0.0407 * *$ \\
\hline $\mathrm{NPL} / \mathrm{CP}$ & 10.14477 & 3.8141 & $0.0008 * * *$ \\
\hline M2/GDP & -0.935527 & 0.7363 & $0.0956^{*}$ \\
\hline Bank rate & 0.434950 & 0.122968 & $0.0009 * * *$ \\
\hline $\mathrm{C}$ & 70.4111 & 12.1027 & $0.00546^{* * *}$ \\
\hline R-squared & 0.852302 & Akaike info criterion & -2.735870 \\
\hline Adjusted R-squared & 0.79120 & F-statistic & 12.1059 \\
\hline S.E. of regression & 0.03455 & Prob (F-statistic) & 0.002000 \\
\hline Log likelihood & 67.0214 & Durbin-Watson stat & 1.8874 \\
\hline \multicolumn{4}{|c|}{ Arch (F-statistic) 0.04 (0.922) } \\
\hline \multicolumn{4}{|c|}{ Jarque-Bera $0.101(0.902)$} \\
\hline \multicolumn{4}{|c|}{ Ramsey reset F-statistic $2.541(0.14)$} \\
\hline \multicolumn{4}{|c|}{ Godfrey serial correlation F-statistic 0.07 (0.867) } \\
\hline
\end{tabular}

Table 4. Cointegration test results

\begin{tabular}{lll}
\hline & ADF statistic & order of integration \\
\hline res & $-3.815164^{* * *}$ & $\mathrm{I}(0)$ \\
\hline
\end{tabular}

Note: (i) critical values at $1 \%, 5 \%$ and $10 \%$ are $-3.5654,-2.9995$ and -2.5979 respectively

The test results reject the null hypothesis of no cointegration among the explanatory variables that is, the bank rate, treasury bill rate, M2 to GDP ratio, ratio of non-performing loans to private sector credit and the exchange rate volatilities with the spread which is the dependent variable at 1 percent level of significance.

\subsection{Error Correction Model}

The Error Correction Model was estimated for the cointegrated variables in Table 4.The results are presented in Table 5 .

Table 5. Estimation of the Error Correction Model by OLS

\begin{tabular}{llll}
\hline $\begin{array}{l}\text { Dependent Variable: D(Spread) } \\
\text { Method: Least Squares }\end{array}$ & & & \\
\hline Variable & Coefficient & Std. Error & Prob. \\
\hline D(Treasury bill rates) & 0.184969 & 0.045907 & 0.0002 \\
D(NPL/CP) & 36.70169 & 16.61079 & 0.0323 \\
D(M2/GDP) & -1.7763 & 0.596810 & 0.0047 \\
D(XRTV) & 0.019595 & 0.006146 & 0.0026 \\
D(Bank rate) & 0.223232 & 0.051786 & 0.0001 \\
ECM(-1) & -0.132565 & 0.040475 & 0.002 \\
C & -0.000750 & 0.004686 & 0.8645 \\
\hline R-squared & 0.82110 & Mean dependent var & 0.00015 \\
Adjusted R-squared & 0.78499 & S.D. dependent var & 0.068294 \\
S.E. of regression & 0.03 & Akaike info criterion & 5.4124 \\
Log likelihood & 104.235 & F-statistic & 15.0005 \\
Durbin-Watson stat & 1.6972 & Prob(F-statistic) & 0.00012 \\
\hline Arch (F-statistic) $0.030(0.91)$ & & & \\
Jarque-Bera 0.112 (0.90) & & & \\
Ramsey reset F-statistic 2.011(0.10) & & \\
Godfrey serial correlation F-statistic $0.064(0.92)$ & & \\
\hline
\end{tabular}

Notes: The asterisk ${ }^{* * *},{ }^{* *}$, and $*$ indicate significance at the 1 percent, 5 percent and 10 percent levels 


\subsubsection{Diagnostic Tests}

Regression results in Table 5 which is the short-run model show the Adjusted R-squared of 0.78 , this implies that the explanatory variables in the short-run model explain 78 percent of the variations in the spread. Results in Table 3 which is the long-run model show that the goodness of fit is satisfactory (Adj. R-squared of 0.79), implying that the explanatory variables in the long-run model explain 79 percent of the variations in the interest rate spread during the 1995-2010 period. The F-statistic of 15.00 with probability value of 0.00012 in the short-run model and 12.11 with probability value of 0.002 in the long-run model indicates that both long-run and short-run models are highly significant.

Furthermore, the Durbin-Watson statistics (DW) of 1.67 and 1.89 for both the short-run and long-run models indicates that there are no major autocorrelation problems. The Jarque-Bera statistics for testing for normality of the residual for the estimated short-run and long-run models are 0.112 and 0.101 , with probability values of 0.909 and 0.902 , respectively. This therefore indicates that the models are normally distributed. The Auto Regressive Conditional Heteroskedasticity (ARCH) for stability of the residuals yields F-statistics of 0.03 and 0.04 with probability values of 0.91 and 0.92 for the short-run and long-run models, respectively. This confirms that the models are stable

In addition, the Ramsey RESET test for specification error yields F-statistics of 2.011 and 2.541, with probability values of 0.10 and 0.14 for both models, respectively. This suggests that the models are not mis-specified. Also, the test for serial correlation among variables in the model using Breusch-Godfrey Serial Correlation LM test was carried out. The results indicate F-statistics of 0.064 and 0.07 , with probability values of 0.92 and 0.87 for the short-run and long-run models, respectively. This confirms no serial correlation among the variables in the models.

\subsubsection{Interpretation of Both Short-run and Long-run Empirical Results}

Empirical results from the error correction model (short-run model) in Table 5 and the long-run model in Table 3 are interpreted from the following sub-section.

\section{Effect of the bank rate}

The coefficient of the bank rate (br) has a positive impact on the interest rate spread as expected. It is also significant at the 1 percent level of significance both in the short run and long run. Assuming all other factors constant, a 1 percent increase in the bank rate would lead to 0.22 percent and 0.43 percent increase in the interest rate spread in the short-run and long-run, respectively. This implies that an increase in the bank rate charged by the central bank on the commercial banks increases the interest rate spread both in the short run and long run in Uganda.

\section{Effect of treasury bill rate}

The coefficient of the treasury bill rate (tb) has a positive impact on the interest rate spread as expected. It is also significant at 1 percent level of significance both in the short-run and long run. Assuming all other factors constant, a 1 percent increase in the treasury bill rate would lead to 0.18 percent and 0.23 percent increase in the interest rate spread in the short-run and long-run, respectively. This implies that an increase in the treasury bill rate increases the interest rate spread both in the short run and long-run in Uganda.

\section{Effect of non-performing loans}

The coefficient of non-performing loans (NPL/CP) has a positive impact on the interest rate spread as expected. It is significant at the 5 and 1 percent level of significance both in the short run and long run level respectively. Assuming all other factors constant, a unit increase in the ratio of non-performing loans to private sector credit would lead to 36.7 and 10.1 percent increase in the interest rate spread in the short-run and long-run, respectively. This means that an increase in the ratio of non-performing loans to private sector credit increases the interest rate spread both in the short run and long run in Uganda.

\section{Effect of exchange rate volatilities}

Similarly, the coefficient of exchange rate volatilities (XRTV) increases the interest rate spread as expected. It is also significant at the 1 and 5 percent levels of significance both in the short-run and long-run. Assuming all other factors constant, a unit increase in volatilities in the exchange rate would lead to a 0.02 and 0.05 percent decrease in the interest rate spread in the short-run and long-run, respectively. This implies that exchange rate volatilities in Uganda decrease the interest rate spread both in the short- run and long- run.

\section{Effect of the financial intermediation ratio (M2/GDP)}

The coefficient of M2/GDP has a negative impact on the interest rate spread as expected. It is also significant at the 
1 percent level of significance in the short-run and significant at the 10 percent level of significance in the long-run. Assuming all other factors constant, a unit increase in M2/GDP would lead to a 1.78 and 0.94 percent decrease in the interest rate spread in the short-run and long-run, respectively. This implies that the level of financial development can be instrumental in reducing the interest rate spread.

Results reveal that the error correction term $\left(\mathrm{ECM}_{(-l)}\right)$ in the model is significant and correctly signed that is, negative as expected and is significant at the 1 percent level. The error correction term $\left(E C M_{(-I)}\right)$ coefficient of 0.133 implies that in each period, the interest rate spread adjusts by 0.13 percent between the current level and the long run equilibrium level.

\section{Conclusion and Policy Implications}

\subsection{Conclusion}

The main objective of this study was to explore empirically the factors that drive the high interest rate spreads in Uganda. The econometric results reveal that the major drivers of interest rate spreads in Uganda include the bank rate, treasury bill rate, non-performing loans, financial intermediation ratio, and real gross domestic product.

\subsection{Policy Implications}

The results from this study identify a number of policy implications on government and bank policy approaches for reducing the interest rate spread and improving the financial sector intermediation in Uganda. Therefore the following policies if well implemented will help to reduce the interest rate spread.

\subsubsection{The Government Should Target to Increase Financial Intermediation}

According to the empirical results, the financial intermediation ratio which is a proxy for the level of financial development measured by M2/GDP is significant and has a negative correlation with the spread. This implies that increasing financial intermediation would lead to increased banking efficiency and hence reduction in the interest rate spread. Financial intermediation can be increased by increasing savings; this can be done by raising the deposit rate so that more deposits are attracted to the financial institutions. It can also be increased by expanding the banking sector by opening up new commercial banks and expansion of branch networks of the banks in addition to sensitizing the public especially in rural areas on how to use the banks. These two measures can increase the deposits in the commercial banks and thus M2.

\subsubsection{Enhance Commercial Courts /Tribunals and Support the Credit Reference Bureau}

The empirical results show that the ratio of non-performing loans to total credit to the private sector is significant and positively related to the spread. This implies that non-performing loans and the spread move in the same direction. In order to perform efficiently and effectively, the mechanism of sharing information on defaulters needs to be performing effectively so as to help commercial banks' reduce on the credit risk. Government should therefore continue to support the Credit Reference Bureau (CRB). This will close the information gap problem, and therefore the risk which brings about problems related to adverse selection and moral hazards. With the implementation of this, the problem of non- performing loans and the spread will reduce

\section{References}

Barajas, A., Steiner, R., \& Salazar, N. (1999). interest rate spreads in Banking; Colombia, 1974-96. IMF Staff Papers, 46, 196-224.

Bank of Uganda. Quarterly and Annual Reports 2000-2008.

Berger, Allen N., \& Timothy H. Hannan. (1989). The Price-Concentration Relationship in banking. Review of Economics and Statistics, 71(2), 291-99. http://dx.doi.org/10.2307/1926975

Beck, T., \& Hesse, H. (2006). Bank Efficiency, Ownership and Market Structure. Why are Interest spreads so high in Uganda? Brownbridge, M., and C. Kirkpatrick, 2000, "Financial Regulation in Developing Countries. Institute for Development Policy and Management Working Paper, 12, University of Manchester.

Caprio, \& Shanaka, J. (2005). Financial Sector Reforms in Uganda 1999-2005. in Uganda. Selected Issues (Washington: International Monetary Fund).

Clarke, Cull, \& Fuchs. (2006). Assessing Credit Risk in Financial Institutions. Commitments. Journal of Financial and Quantitative Analysis, 24, 489-501

Demirguc-Kunt, Asli, \& Huizinga, Harry. (1998). Determinants of Commercial Bank Interest Margins and Profitability: Some International Evidence. World Bank Policy Working Papers, WPS1900.

Demirguc-Kunt, Asli, \& Huizinga, Harry. (1999). Determinants of Commercial Bank Interest Margins and 
Profitability: Some International Evidence. World Bank Economic Review, 13, 379-408. http://dx.doi.org/10.1093/wber/13.2.379

Dickey, D. A., \& Fuller, W. A. (1979). Distribution of estimators for Autoregressive time series and unit Roots. Journal of American Statistical Association, 74(366), 427-31. http://dx.doi.org/10.2307/2286348

Engle, R., \& Granger, C. (1987). Cointegration and Error Correction: Representation, estimation and Testing. Econometrica, 55(2), 251-78. http://dx.doi.org/10.2307/1913236

Hannan, T., \& Liang, J. N. (1993). Bank Commercial Lending and the Influence of Thrift Competition. Finance and Economics Discussion Series 93-39. Washington: U.S. Board of Governors of the Federal Reserve System.

Kasekende, L. A., \& Ating-Ego, M. (2003). Financial Liberalization and its implication for the domestic system: The case of Uganda. AERC Research Paper, No. 128.

Kasekende. (2008). Plenary session on financial services and economic development: Uganda's experience with financial sector reforms. Journal of African economies, 16.

Meyer, R. L., Roberts, R., \& Mugume, A. (2004). Developing Rural Financial Markets in Uganda: The Way Forward. A report prepared for the Financial System Development Programme, Bank of Uganda/GTZ/KfW/Sida.

McKinnon, R. I. (1973). Money and Capital in Economic Development, (Washington: The Brookings Institution).

Moore, Winston, \& Craigwell, Roland. (2000). Market Power and Interest Rate Spreads.

Ndung'u, Njuguna, \& Ngugi, Rose W. (2000). Banking Sector Interest Rate Spreads in Kenya. Kenya Institute for Public Policy Research and Analysis Discussion Paper, No. 5.

Randall, Ruby. (1998). Interest Rate Spreads in the Eastern Caribbean. (IMF Working Paper, WP/98/59).

Robinson, John W. (2002). Commercial Bank Interest Rate Spreads in Jamaica. (IMF Working Paper, $\mathrm{WP} / 100 / 78)$.

Samuel, \& Valderrama. (2006). The Monetary Policy Regime and Banking spreads in Barbados. (IMF Working Paper, WP/06/211).

Shaw, E. M. (1973). Financial Deepening in Economic Development, (Oxford: Oxford University Press).

Sologoub, Dmitry. (2006). The determinants of Bank Interest Margins and Profitability: the case of developing countries. (IMF Working Paper, WP/06/221). 